\title{
Keanekaragaman Reptil Impor Di Yogyakarta
}

\author{
Diversity of Imported Reptiles in Yogyakarta \\ Dicky Indar Putranto, Pramana Yuda*, Felicia Zahida* \\ Fakultas Teknobiologi, Universitas Atma Jaya Yogyakarta, Jl. Babarsari 44 Yogyakarta 55281 \\ E-mail: dicky.ipe@gmail.com*Penulis untuk korespondensi
}

\begin{abstract}
Abstrak : Reptil impor banyak diminati karena memiliki variasi warna yang sangat beragam. Penelitian ini mengenai jenis reptil eksotik apa saja yang ada di Yogyakarta baik yang dipelihara maupun yang sudah terlepas atau dilepas di alam dan bagaimana pula potensi dampaknya bagi spesies reptil lokal yang ada di Yogyakarta. Penelitian ini dilakukan di wilayah Kota Yogyakarta dengan melakukan survei di pasar hewan, petshop dan pemelihara reptil. Penelitian ini telah dilaksanakan dari tanggal 1 Agustus 2013 sampai 30 November 2013. Berdasarkan hasil survei pendataan reptil impor yang dipelihara di Yogyakarta, ditemukan 80 jenis yang terdiri dari satu jenis buaya kerdil (Paleosuchus palpebrosus), 14 jenis kadal (Sauria), 21 jenis ular (Serpentes), dan 44 jenis Kurakura (Testudines). Reptil impor yang terlepas di alam ditemukan beberapa jenis, yaitu dua ekor Red Eared Slider (Trachemys scripta elegans), tiga ekor Chinese Soft-shelled Turtle (Pelodiscus sinensis) dan satu ekor Corn snake (Pantherophis guttatus). Red Eared Slider yang terlepas di alam dalam jumlah tersebut tidak dapat menimbulkan dampak negatif bagi reptil lokal, tetapi jika dalam jumlah yang banyak kemungkinan akan berpotensi sebagai kompetitor bagi bulus jawa (Amyda cartilaginea) dalam mencari makan. Chinese Soft-shelled Turtle yang terlepas di alam dalam jumlah tersebut kemungkinan akan berpotensi sebagai kompetitor bagi Amyda cartilaginea dalam mencari makan. Corn snake yang hanya satu ekor jika terlepas tidak dapat menimbulkan dampak negatif bagi reptil lokal, tetapi jika jumlahnya terlalu banyak akan menjadi kompetitor bagi ular-ular lokal seperti ular koros (Ptyas korros), ular jali (Ptyas mucosa), ular kopi (Coelognathus flavolineatus), ular lanang sapi (Coelognathus radiatus), dan lainlain, karena jenis mangsa yang sama.

Kata kunci : Reptil, reptil impor, keanekaragaman.
\end{abstract}

\section{PENDAHULUAN}

Reptil adalah hewan vertebrata yang terdiri dari ular, kadal cacing, kadal, buaya, Caiman, buaya, kura-kura, penyu dan tuatara. Ada sekitar 7900 spesies reptil hidup sampai saat ini yang mendiami berbagai tipe habitat beriklim sedang 
dan tropis termasuk padang pasir, hutan, lahan basah air tawar, hutan bakau dan laut terbuka (Klappenbach, 2013).

Dulu reptil dianggap menakutkan, harus dihindari bahkan dimusnahkan. Hal tersebut disebabkan karena sebagian besar reptil dikira sebagai hewan liar yang berbahaya dan berbisa. Namun, sekarang ini pandangan itu telah berubah dan banyak orang yang senang memelihara hewan melata ini karena keunikan atau variasi warna dari reptil. Variasi dan keunikan-keunikan tersebut yang menarik perhatian para pecinta satwa untuk menangkarkan dan mengembangbiakkan reptil.

Menurut Mardiastuti dan Soehartono (2002), perdagangan reptil internasional sebagai binatang peliharaan telah dimulai tahun 1980. Pada tahun 1999, sebanyak 161 spesies reptil hidup tercatat diperjualbelikan. Contoh jenis ular yang dipelihara adalah sanca batik (Broghammerus reticulatus) dan boa (Boa constrictor). Bulan September 2010 dan April 2011, telah dilakukan penelitian terhadap para pedagang reptil di Provinsi Maluku, Papua Barat dan Papua. Beberapa spesies yang banyak diperdagangkan, diantaranya: ular piton hijau (Morelia viridis), ular piton boelen (Morelia boeleni), kadal leher berumbai (Clamydosaurus kingii), kadal lidah biru (Tiliqua Scincoides), dan beberapa spesies dari biawak (Varanus spp.) (Lyons dan Natusch, 2011).

Indonesia memiliki keanekaragaman reptil yang melimpah, berdasarkan koleksi herpetofauna dari berbagai daerah di Indonesia yang tersimpan di Museum Zoologi Bogor dapat diketahui bahwa Indonesia memiliki sekitar 1.500 jenis reptil (Tjakrawidjaja, 2010). Negara-negara lain juga memiliki jenis-jenis reptil yang 
sangat beragam, sehingga reptil juga menjadi komoditas impor. Reptil impor atau reptil eksotik banyak diminati karena memiliki variasi warna yang sangat beragam. Namun jika keberadaannya berlebihan dan tidak sengaja lepas ke alam liar bisa berpotensi menjadi spesies invasif dan mengancam spesies lokal.

Di Yogyakarta, beberapa pedagang pasar hewan maupun pemilik petshop telah menawarkan reptil impor kepada kolektor reptil. Begitu pula dengan para kolektor reptil yang membeli reptil impor melalui pedagang pasar hewan dalam kota maupun luar kota. Sehingga reptil impor kini sudah banyak yang beredar di Yogyakarta. Laporan kerja praktik oleh Putranto (2012) dengan judul pola distribusi kepemilikan reptil impor di yogyakarta, pada bulan Juli-Agustus 2012, didapatkan data reptil eksotik sebanyak 72 spesies dipelihara penghobi reptil di Yogyakarta. Maka dari itu perlu dilakukan penelitian lanjutan mengenai jenis reptil eksotik apa saja yang ada di Yogyakarta baik yang dipelihara maupun yang sudah terlepas atau di lepas di alam. Bagaimana pula potensi dampaknya bagi spesies reptil lokal yang ada di Yogyakarta.

\section{METODE PENELITIAN}

\section{Alat dan Bahan}

Alat dan bahan yang digunakan dalam penelitian ini adalah kamera, buku catatan, pensil, penggaris, data base di internet (reptile-database.org), stick hook (alat untuk menangkap ular), senter dan karung. 


\section{Reptil impor yang dipelihara}

Data keanekaragaman reptil eksotik dilakukan dengan pengamatan langsung di 20 lokasi yang terdiri dari pedagang pasar ada 3 lokasi, dari petshop ada 2 lokasi, dari pemelihara reptil ada 14 lokasi dan 1 lokasi di Kebun Binatang Gembira Loka. Pendataan dilakukan dengan menggunakan buku catatan untuk mendata reptil eksotik yang ada di pedagang reptil, petshop, kebun binatang, maupun orang pemelihara reptil. Reptil eksotik yang ditemui di setiap lokasi dicatat nama lokal, jumlah setiap jenis, asal spesies tersebut, jenis kelaminnya dan ditanyakan jenis mangsa atau makanan dari reptil tersebut. Jenis reptil eksotik yang ditemukan diidentifikasi dengan melihat ciri-ciri fisik yang khas dari reptil tersebut (morfologi, warna dan motif), diukur SVL (Snout to Vent Length) yaitu panjang badannya dan STL (Snout to Tail Length) yaitu panjang badan + ekor, data kemudian dicocokan di database yang ada di internet (reptile-database.org) sebagai informasi tambahan. Pustaka tentang spesies reptil yang terdapat dalam data tersebut di cari.

\section{Reptil impor yang terlepas di alam}

Data untuk keanekaragaman reptil impor yang terlepas di alam diperoleh dengan melakukan wawancara kepada pemilik reptil saat pengambilan data. Wawancara dilakukan dengan menanyakan apakah pemilik reptil tersebut pernah sengaja melepas reptilnya ke alam atau tidak sengaja terlepas. Dari hasil informasi tersebut kemudian dilakukan cek ke lapangan. Teknik sampling yang digunakan pada saat di lapangan adalah dengan metode survei lapangan. Survei lapangan kelompok reptil umumnya dilakukan dengan menggunakan teknik penangkapan 
individu. Teknik penangkapan dipakai dengan alasan karena pada umumnya reptil bersifat pemalu, penakut dan tersembunyi, sehingga tidak semua anggota populasi dapat terlihat dan lebih banyak informasi yang diperoleh, seperti ukuran tubuh, jenis kelamin dan sebagainya. Teknik penangkapan bervariasi disesuaikan dengan perilaku dan habitatnya (Riyanto dan Mumpuni, 2003).

Penelitian ini mengguanakan metode jelajah dan penghitungan langsung dengan menyusuri sungai/anak sungai. Menurut Riyanto dan Mumpuni (2003), Penghitungan langsung dengan menyusuri sungai/anak sungai digunakan untuk menghitung reptil yang ada di sungai. Pada prinsipnya pelaksana survei menghitung dan mencatat jumlah individu yang dijumpai di sepanjang sungai atau anak sungai yang disurvei sesuai dengan masing-masing habitat reptil yang disurvei.

Data mengenai informasi mangsa atau makanan dari reptil impor dapat dijadikan referensi untuk melakukan observasi langsung ke lapangan dengan mengamati apakah reptil impor tersebut merupakan kompetitor bagi sesama jenisnya, predator bagi spesies lokal atau hama bagi pertanian.

\section{HASIL DAN PEMBAHASAN}

Reptil impor yang dipelihara

Hasil survei di pasar hewan yang menjual berbagai macam jenis reptil, petshop dan pemelihara reptil di Yogyakarta, ditemukan berbagai macam jenis reptil lokal maupun reptil impor. Jenis reptil impor yang diperdagangkan maupun dipelihara ditemukan ada 80 jenis dari 20 lokasi dapat dilihat pada Tabel 1. 
Tabel 1. Keanekaragaman Jenis Reptil Impor yang Diperdagangkan dan Dipelihara Di Yogyakarta. Ket : (a: Kebun Binatang, b: Pasar, c: Petshop, d: kolektor)

\begin{tabular}{|c|c|c|c|c|c|c|c|c|}
\hline \multirow[t]{2}{*}{ No. } & \multirow[t]{2}{*}{ Jenis } & \multirow[t]{2}{*}{ Nama ilmiah } & \multirow[t]{2}{*}{ Asal } & \multicolumn{4}{|c|}{$\begin{array}{c}\text { Jumlah } \\
\text { menurut lokasi }\end{array}$} & \multirow[t]{2}{*}{ Jumlah } \\
\hline & & & & $\mathbf{a}$ & $\mathbf{b}$ & c & d & \\
\hline \multicolumn{9}{|c|}{ Ordo Crocodylia } \\
\hline 1 & Dwarf Caiman & $\begin{array}{l}\text { Paleosuchus } \\
\text { palpebrosus }\end{array}$ & $\begin{array}{l}\text { Amerika } \\
\text { Selatan }\end{array}$ & 2 & - & - & - & 2 \\
\hline \multicolumn{9}{|c|}{ Sub-Ordo Sauria } \\
\hline 2 & Golden Tegu & Tupinambis teguixin & $\begin{array}{l}\text { Amerika } \\
\text { Selatan }\end{array}$ & - & 1 & 10 & - & 11 \\
\hline 3 & $\begin{array}{l}\text { Argentine Black and } \\
\text { White Tegu }\end{array}$ & Salvator merianae & $\begin{array}{l}\text { Amerika } \\
\text { Selatan }\end{array}$ & 6 & 1 & 3 & 2 & 12 \\
\hline 4 & Giant Ameiva & Ameiva ameiva & $\begin{array}{l}\text { Amerika } \\
\text { Selatan }\end{array}$ & 4 & - & 1 & - & 5 \\
\hline 5 & Feuerskink & $\begin{array}{l}\text { Lepidothyris } \\
\text { fernandi }\end{array}$ & $\begin{array}{l}\text { Afrika } \\
\text { Tengah }\end{array}$ & 2 & - & - & - & 2 \\
\hline 6 & Gila Monster & $\begin{array}{l}\text { Heloderma } \\
\text { suspectum }\end{array}$ & $\begin{array}{l}\text { Amerika } \\
\text { Utara }\end{array}$ & 1 & - & - & - & 1 \\
\hline 7 & Madagascar Day Gecko & $\begin{array}{l}\text { Phelsuma } \\
\text { madagascariensis }\end{array}$ & Madagascar & 1 & - & - & - & 1 \\
\hline 8 & Roughtail Rock Agama & Stellagama stellio & Mesir & 2 & - & 2 & - & 4 \\
\hline 9 & Panther Chameleon & Fucifer pardalis & Madagascar & 1 & - & - & - & 1 \\
\hline 10 & Green Iguana & Iguana iguana & $\begin{array}{l}\text { Amerika } \\
\text { Selatan }\end{array}$ & 13 & 7 & 14 & 30 & 64 \\
\hline 11 & Leopard Gecko & $\begin{array}{l}\text { Eublepharis } \\
\text { macularius }\end{array}$ & Pakistan & 2 & 9 & - & 39 & 50 \\
\hline 12 & Bearded Dragon & Pogona vitticeps & Australia & 4 & - & - & 5 & 9 \\
\hline 13 & Savannah Monitor & $\begin{array}{l}\text { Varanus } \\
\text { exanthematicus }\end{array}$ & Afrika & 2 & 1 & - & - & 3 \\
\hline 14 & African Fat Tail Gecko & $\begin{array}{l}\text { Hemitheconyx } \\
\text { caudicinctus }\end{array}$ & Afrika & - & - & 5 & - & 5 \\
\hline 15 & Collared Lizard & Crotaphytus collaris & $\begin{array}{l}\text { Amerika } \\
\text { Utara }\end{array}$ & - & - & - & 2 & 2 \\
\hline \multicolumn{9}{|c|}{ Sub-Ordo Serpentes } \\
\hline 16 & Green Anaconda & Eunectes murinus & $\begin{array}{l}\text { Amerika } \\
\text { Selatan }\end{array}$ & 1 & - & - & - & 1 \\
\hline 17 & Yellow Anaconda & Eunectes notaeus & $\begin{array}{l}\text { Amerika } \\
\text { Selatan }\end{array}$ & - & - & 2 & - & 2 \\
\hline 18 & Rainbow Boa & Epicrates cenchria & $\begin{array}{l}\text { Amerika } \\
\text { Selatan }\end{array}$ & 1 & - & - & - & 1 \\
\hline 19 & Woma Python & Aspidites ramsayi & Australia & 1 & - & - & - & 1 \\
\hline 20 & Ball Python & Python regius & Afrika & 2 & 15 & 19 & 5 & 41 \\
\hline 21 & Sahara Sandboa & Eryx muelleri & Afrika & 1 & - & - & - & 1 \\
\hline 22 & Gabon Adder & Bitis gabonica & Afrika & 1 & - & - & - & 1 \\
\hline
\end{tabular}




\begin{tabular}{|c|c|c|c|c|c|c|c|c|}
\hline \multirow{2}{*}{ No. } & \multirow{2}{*}{ Jenis } & \multirow{2}{*}{ Nama ilmiah } & \multirow[t]{2}{*}{ Asal } & \multicolumn{4}{|c|}{\begin{tabular}{|c|} 
Jumlah \\
menurut lokasi
\end{tabular}} & \multirow[t]{2}{*}{ Jumlah } \\
\hline & & & & $\mathbf{a}$ & $\mathbf{b}$ & $\mathbf{C}$ & d & \\
\hline 23 & Milk snake & $\begin{array}{l}\text { Lampropeltis } \\
\text { triangulum }\end{array}$ & $\begin{array}{l}\text { Amerika } \\
\text { Utara }\end{array}$ & 5 & 1 & 2 & - & 8 \\
\hline 24 & Corn snake & $\begin{array}{l}\text { Pantherophis } \\
\text { guttatus }\end{array}$ & $\begin{array}{l}\text { Amerika } \\
\text { Utara }\end{array}$ & 4 & 6 & - & 1 & 11 \\
\hline 25 & King snake & Lampropeltis getula & $\begin{array}{l}\text { Amerika } \\
\text { Utara }\end{array}$ & 6 & 1 & - & - & 7 \\
\hline 26 & Bug eyed ratsnake & $\begin{array}{l}\text { Pantherophis } \\
\text { obsoletus }\end{array}$ & $\begin{array}{l}\text { Amerika } \\
\text { Utara }\end{array}$ & 2 & 4 & - & - & 4 \\
\hline 27 & Boa constrictor & Boa constrictor & $\begin{array}{l}\text { Amerika } \\
\text { Selatan }\end{array}$ & - & 5 & 19 & - & 24 \\
\hline 28 & $\begin{array}{l}\text { North Philippine temple } \\
\text { pitviper }\end{array}$ & $\begin{array}{l}\text { Tropidolaemus } \\
\text { subannulatus }\end{array}$ & Filipina & - & 1 & 1 & - & 2 \\
\hline 29 & Brown House Snake & Boaedon fuliginosus & Afrika & - & - & 1 & - & 1 \\
\hline 30 & Dwarf Puff Adder & Bitis peringueyi & Namibia & - & - & 1 & - & 1 \\
\hline 31 & Cape Coral Snake & Aspidelaps lubricus & Afrika & - & - & 1 & - & 1 \\
\hline 32 & African rock python & Python sebae & Afrika & - & - & 1 & - & 1 \\
\hline 33 & $\begin{array}{l}\text { Central American } \\
\text { Rattle Snake } \\
\end{array}$ & Crotalus simus & $\begin{array}{l}\text { Amerika } \\
\text { Tengah }\end{array}$ & - & - & 1 & - & 1 \\
\hline 34 & Amazon tree boa & Corallus hortulanus & $\begin{array}{l}\text { Amerika } \\
\text { Selatan }\end{array}$ & - & - & 1 & - & 1 \\
\hline 35 & $\begin{array}{l}\text { Diamond back rattle } \\
\text { snake }\end{array}$ & Crotalus atrox & $\begin{array}{l}\text { Amerika } \\
\text { Tengah }\end{array}$ & - & - & - & 1 & 1 \\
\hline 36 & Monocled Cobra & Naja kaouthia & Myanmar & - & - & - & 1 & 1 \\
\hline \multicolumn{9}{|c|}{ Ordo Testudines } \\
\hline 37 & Pond Slider & Trachemys scripta & $\begin{array}{l}\text { Amerika } \\
\text { Utara } \\
\end{array}$ & 16 & 42 & - & 35 & 93 \\
\hline 38 & $\begin{array}{l}\text { Chinese Striped-necked } \\
\text { Turtle }\end{array}$ & Mauremys sinensis & Cina & 1 & - & - & 13 & 14 \\
\hline 39 & $\begin{array}{l}\text { Yellow-spotted Amazon } \\
\text { River Turtle }\end{array}$ & Podocnemis unifilis & $\begin{array}{l}\text { Amerika } \\
\text { Selatan }\end{array}$ & 4 & - & - & 3 & 7 \\
\hline 40 & Spotted Pond turtle & $\begin{array}{l}\text { Geoclemys } \\
\text { hamiltonii }\end{array}$ & Pakistan & 1 & - & - & 2 & 3 \\
\hline 41 & Diamond back terrapin & Malaclemys terrapin & Florida & 2 & - & - & 4 & 6 \\
\hline 42 & Mata mata & Chelus fimbriatus & $\begin{array}{l}\text { Amerika } \\
\text { Selatan }\end{array}$ & 2 & 4 & 9 & - & 15 \\
\hline 43 & Aligator snapping turtle & $\begin{array}{l}\text { Macrochelys } \\
\text { temminckii }\end{array}$ & $\begin{array}{l}\text { Amerika } \\
\text { Utara }\end{array}$ & 2 & 1 & - & 6 & 9 \\
\hline 44 & False map turtle & $\begin{array}{l}\text { Graptemys } \\
\text { pseudogeographica }\end{array}$ & $\begin{array}{l}\text { Amerika } \\
\text { Utara }\end{array}$ & - & 1 & - & 8 & 9 \\
\hline 45 & African Mud Turtle & Pelusios castaneus & Afrika & - & 1 & 5 & 2 & 8 \\
\hline 46 & Stinkpot Turtle & $\begin{array}{l}\text { Sternotherus } \\
\text { odoratus }\end{array}$ & $\begin{array}{l}\text { Amerika } \\
\text { Utara }\end{array}$ & - & 1 & 6 & 3 & 10 \\
\hline 47 & Painted Wood Turtle & $\begin{array}{l}\text { Rhinoclemmys } \\
\text { pulcherrima }\end{array}$ & $\begin{array}{l}\text { Amerika } \\
\text { Tengah }\end{array}$ & - & 2 & - & 1 & 3 \\
\hline
\end{tabular}




\begin{tabular}{|c|c|c|c|c|c|c|c|c|}
\hline \multirow{2}{*}{ No. } & \multirow{2}{*}{ Jenis } & \multirow{2}{*}{ Nama ilmiah } & \multirow{2}{*}{ Asal } & \multicolumn{4}{|c|}{$\begin{array}{c}\text { Jumlah } \\
\text { menurut lokasi }\end{array}$} & \multirow{2}{*}{ Jumlah } \\
\hline & & & & $\mathbf{a}$ & $\mathbf{b}$ & $\mathbf{C}$ & d & \\
\hline 48 & $\begin{array}{l}\text { Common snapping } \\
\text { turtle }\end{array}$ & Chelydra serpentina & $\begin{array}{l}\text { Amerika } \\
\text { Utara }\end{array}$ & - & 1 & - & 7 & 8 \\
\hline 49 & $\begin{array}{l}\text { Chinese Soft-shelled } \\
\text { Turtle }\end{array}$ & Pelodiscus sinensis & Cina & - & 6 & - & 7 & 13 \\
\hline 50 & Helmeted Turtle & Pelomedusa subrufa & Afrika & - & - & 5 & 4 & 9 \\
\hline 51 & $\begin{array}{l}\text { Indian Flap-shelled } \\
\text { Turtle }\end{array}$ & Lissemys punctata & India & - & - & - & 5 & 5 \\
\hline 52 & $\begin{array}{l}\text { Burmese Flap-shelled } \\
\text { Turtle }\end{array}$ & Lissemys scutata & Myanmar & - & - & - & 3 & 3 \\
\hline 53 & Florida softshell turtle & Apalone ferox & Florida & - & - & - & 2 & 2 \\
\hline 54 & Spiny Softshell Turtle & Apalone spinifera & $\begin{array}{l}\text { Amerika } \\
\text { Utara }\end{array}$ & - & - & - & 3 & 3 \\
\hline 55 & Razorback Musk Turtle & $\begin{array}{l}\text { Sternotherus } \\
\text { carinatus }\end{array}$ & $\begin{array}{l}\text { Amerika } \\
\text { Utara }\end{array}$ & - & - & - & 6 & 6 \\
\hline 56 & Reeves' Turtle & Mauremys reevesii & $\begin{array}{l}\text { Amerika } \\
\text { Utara }\end{array}$ & - & - & - & 11 & 11 \\
\hline 57 & Florida Redbelly Turtle & Pseudemys nelsoni & $\begin{array}{l}\text { Amerika } \\
\text { Utara }\end{array}$ & - & - & - & 2 & 2 \\
\hline 58 & $\begin{array}{l}\text { Alabama Redbelly } \\
\text { Turtle }\end{array}$ & $\begin{array}{l}\text { Pseudemys } \\
\text { alabamensis }\end{array}$ & $\begin{array}{l}\text { Amerika } \\
\text { Utara }\end{array}$ & - & - & - & 2 & 2 \\
\hline 59 & Southern Painted Turtle & Chrysemys dorsalis & $\begin{array}{l}\text { Amerika } \\
\text { Utara }\end{array}$ & - & - & - & 2 & 2 \\
\hline 60 & Painted Turtle & Chrysemys picta & Kanada & - & - & - & 16 & 16 \\
\hline 61 & Cuban Slider & Trachemys decussata & Kuba & - & - & - & 3 & 3 \\
\hline 62 & Gabon Turtle & Pelusios gabonensis & Afika & - & - & - & 2 & 2 \\
\hline 63 & Japanese Pond Turtle & Mauremys japonica & Jepang & - & - & - & 1 & 1 \\
\hline 64 & $\begin{array}{l}\text { Yellow-headed Temple } \\
\text { Turtle }\end{array}$ & Heosemys annandalii & Thailand & - & - & - & 1 & 1 \\
\hline 65 & \begin{tabular}{|l|}
$\begin{array}{l}\text { Hilaire's Side-necked } \\
\text { Turtle }\end{array}$ \\
\end{tabular} & Phrynops hillari & $\begin{array}{l}\text { Amerika } \\
\text { Selatan }\end{array}$ & - & - & - & 5 & 5 \\
\hline 66 & Indian Roofed Turtle & Pangshura tecta & India & - & - & - & 1 & 1 \\
\hline 67 & Striped Mud Turtle & Kinosternon baurii & Florida & - & - & - & 1 & 1 \\
\hline 68 & Eastern River Cooter & Pseudemys concinna & $\begin{array}{l}\text { Amerika } \\
\text { Utara }\end{array}$ & - & - & - & 2 & 2 \\
\hline 69 & Burmese Eyed Turtle & Morenia ocellata & Myanmar & - & - & - & 1 & 1 \\
\hline 70 & Indian Black turtle & Melanochelys trijuga & India & - & - & - & 1 & 1 \\
\hline 71 & Aldabra Giant Tortoise & $\begin{array}{l}\text { Aldabrachelys } \\
\text { gigantea }\end{array}$ & $\begin{array}{l}\text { Aldabra } \\
\text { Atoll }\end{array}$ & 2 & - & - & 6 & 8 \\
\hline 72 & Indian star tortoise & Geochelone elegans & India & - & 2 & 16 & 12 & 30 \\
\hline 73 & $\begin{array}{l}\text { African Spurred } \\
\text { Tortoise }\end{array}$ & Geochelone sulcata & $\begin{array}{l}\text { Afrika } \\
\text { Tengah } \\
\end{array}$ & - & 3 & - & 17 & 20 \\
\hline 74 & Elongated Tortoise & Indotestudo elongata & Myanmar & - & - & - & 2 & 2 \\
\hline 75 & Radiated Tortoise & Astrochelys radiata & Madagascar & - & - & - & 14 & 14 \\
\hline
\end{tabular}




\begin{tabular}{|c|c|c|c|c|c|c|c|c|}
\hline \multirow[t]{2}{*}{ No. } & \multirow{2}{*}{ Jenis } & \multirow{2}{*}{ Nama ilmiah } & \multirow{2}{*}{ Asal } & \multicolumn{4}{|c|}{$\begin{array}{c}\text { Jumlah } \\
\text { menurut lokasi }\end{array}$} & \multirow[t]{2}{*}{ Jumlah } \\
\hline & & & & $\mathbf{a}$ & b & C & d & \\
\hline 76 & Leopard Tortoise & $\begin{array}{l}\text { Stigmochelys } \\
\text { pardalis }\end{array}$ & $\begin{array}{l}\text { Afrika } \\
\text { Selatan }\end{array}$ & - & - & - & 4 & 4 \\
\hline 77 & Red-footed Tortoise & $\begin{array}{l}\text { Chelonoidis } \\
\text { carbonaria }\end{array}$ & $\begin{array}{l}\text { Amerika } \\
\text { Selatan }\end{array}$ & - & - & - & 2 & 2 \\
\hline 78 & $\begin{array}{l}\text { Bell's Hingeback } \\
\text { Tortoise }\end{array}$ & Kinixys belliana & Afrika & - & - & - & 1 & 1 \\
\hline 79 & Madagascan tortoise & $\begin{array}{l}\text { Astrochelys } \\
\text { yniphora }\end{array}$ & Madagascar & - & - & - & 2 & 2 \\
\hline 80 & Horsfield's Tortoise & Testudo horsfieldii & Rusia & - & - & - & 1 & 1 \\
\hline
\end{tabular}

Kota-kota besar di Indonesia banyak yang memperdagangkan reptil sebagai hewan peliharaan, contohnya di DKI Jakarta. Jumlah ketersediaan reptil sebagai hewan peliharaan terbanyak pada kelima pasar tradisional di DKI Jakarta tercatat di Pasar Kartini dengan 36 jenis reptil. Pada Pasar Barito tersedia 18 jenis reptil, Pasar Sumenep 17 jenis, Pasar Kemuning 17 jenis dan hanya 12 jenis pada Pasar Pramuka. Berdasarkan keseluruhan pengamatan dari lima pasar tradisional yan dijadikan lokasi penelitian, dijumpai 52 jenis reptil yang terdiri dari 26 jenis kurakura, 23 jenis ular dan tiga jenis kadal (Daniel, 2011).

Hasil survei pendataan reptil impor yang dipelihara di Yogyakarta, ditemukan 80 jenis reptil impor yang terdiri dari satu jenis buaya kerdil caiman (Paleosuchus palpebrosus), 14 jenis kadal (Sauria), 21 jenis ular (Serpentes), dan 44 jenis Kura-kura (Testudines) dapat dilihat pada Gambar 1. 


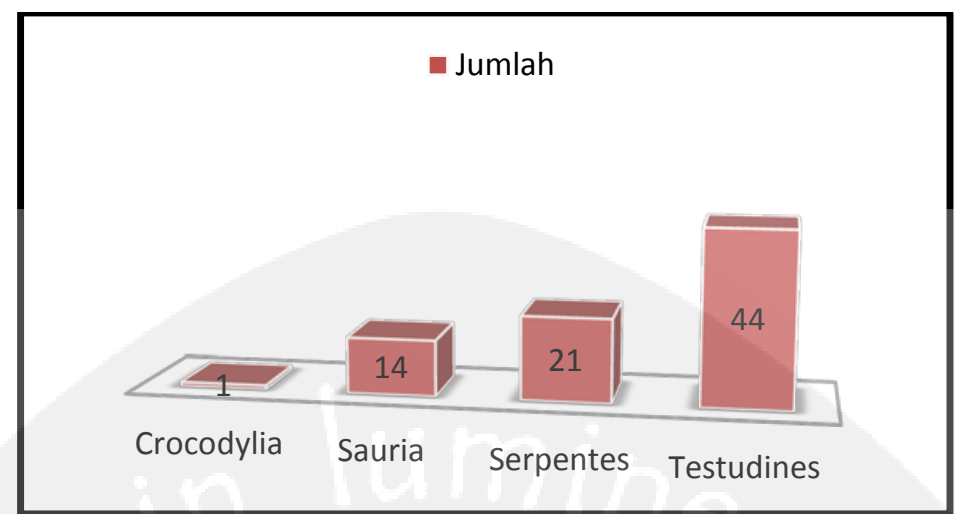

Gambar 1. Jumlah Spesies tiap Ordo/Sub-ordo

Sub-ordo sauria, jenis yang favorit dipelihara adalah iguana (Iguana iguana) dan leopard gecko (Eublepharis macularius). Iguana ditemukan sebanyak 64 individu di Yogyakarta dan merupakan salah satu reptil yang paling digemari karena selain memiliki morfologi yang unik, iguana merupakan jenis binatang herbivora sehingga perawatanya mudah. Leopard gecko (Eublepharis macularius) merupakan salah satu jenis reptil impor yang banyak ditemukan di pemelihara reptil, di Yogyakarta ditemukan sebanyak 50 individu.

Sub-ordo serpentes, jenis Ball python (Python regius) dan Boa constrictor (Boa constrictor) merupakan jenis ular yang digemari karena kedua ular itu memiliki banyak corak motif atau morph. Ball python ditemukan sebanyak 41 individu di Yogyakarta. Boa constrictor ditemukan sebanyak 24 individu.

Ordo testudines, jenis yang paling banyak di pelihara adalah jenis pond turtle (Trachemys scripta) sebanyak 93 individu dan Indian star tortoise (Geochelone elegans) sebanyak 30 individu.

Reptil impor yang ditemukan berasal dari 22 negara di seluruh dunia. Jumlah spesies reptil paling banyak berasal 23\% dari Amerika Utara, 18 \% dari 
Amerika Selatan dan 15\% dari Afrika. Asal spesies reptil impor yang ditemukan di Yogyakarta dapat dilihat pada Gambar 2.

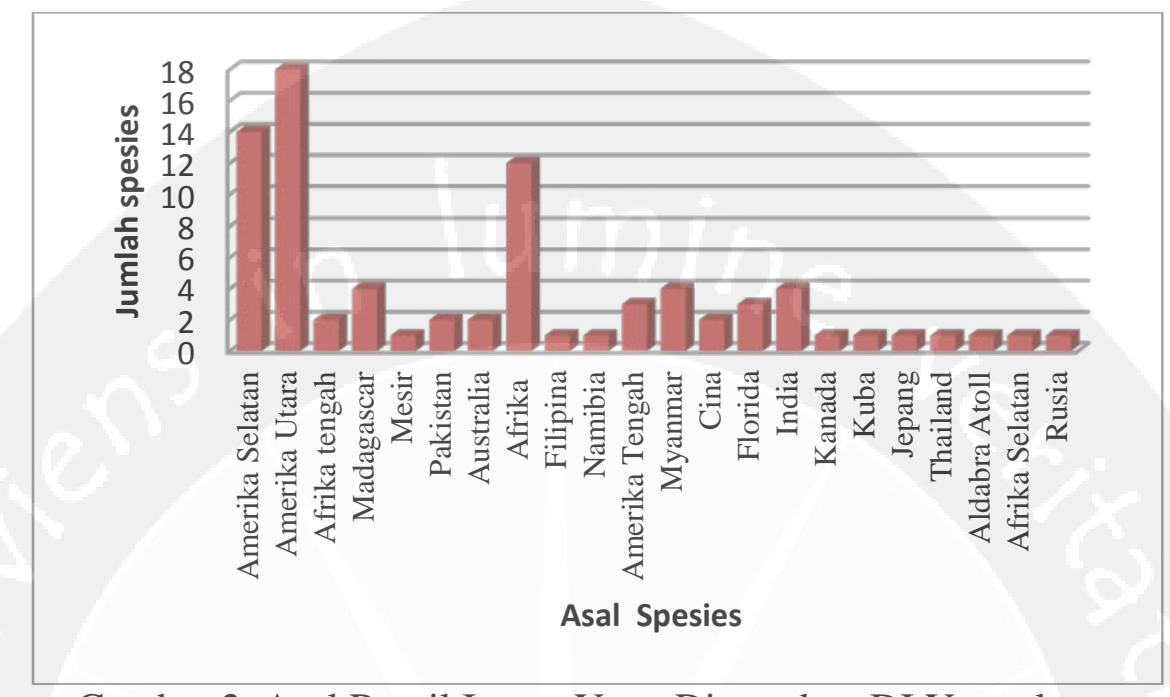

Gambar 2. Asal Reptil Impor Yang Ditemukan DI Yogyakarta

Reptil impor yang diperdagangkan pada pasar tradisional dan toko hewan peliharaan di DKI Jakarta mempunyai daerah asal yang cukup beragam. Daerah asal reptil impor yang diperdagangkan di DKI Jakarta, mayoritas dari Benua Amerika (30 jenis), lalu diikuti Benua Afrika dengan sebelas jenis dan Benua Asia (sebelas jenis) (Daniel, 2011). Sedangkan di Yogyakarta sendiri reptil impor yang di temukan paling banyak berasal dari Amerika Utara (18 jenis), Amerika Selatan (14 jenis), dan Afrika (12 jenis).

Reptil impor yang terlepas di alam

Unsur kesengajaan dan kelalaian dalam memelihara reptil merupakan penyebab reptil impor tersebut bisa terlepas di alam. Hasil survei lapangan dan hasil informasi dari narasumber ditemukan beberapa jenis reptil impor yaitu dua ekor Red Eared Slider (Trachemys scripta elegans), tiga ekor Chinese Soft-shelled 
Turtle (Pelodiscus sinensis) dan seekor Corn snake (Pantherophis guttatus). Jenis reptil impor yang terlepas di alam Yogyakarta dapat dilihat pada Tabel 2.

Tabel 2. Jenis Reptil Impor yang Terlepas Di Alam Yogyakarta

\begin{tabular}{|l|l|l|l|l|}
\hline Lokasi & Jenis & Nama Ilmiah & $\begin{array}{l}\text { Jenis } \\
\text { kelamin }\end{array}$ & $\begin{array}{l}\text { Ukuran } \\
\text { panjang } \\
\text { tubuh }\end{array}$ \\
\hline Tempel & Red Eared Slider & $\begin{array}{l}\text { Trachemys scripta } \\
\text { elegans }\end{array}$ & Betina & $23 \mathrm{~cm}$ \\
\hline Minomartani & Red Eared Slider & $\begin{array}{l}\text { Trachemys scripta } \\
\text { elegans }\end{array}$ & Jantan & $15 \mathrm{~cm}$ \\
\hline $\begin{array}{l}\text { Anak sungai } \\
\text { Progo }\end{array}$ & $\begin{array}{l}\text { Chinese Soft-shelled } \\
\text { Turtle }\end{array}$ & Pelodiscus sinensis & Jantan & $17 \mathrm{~cm}$ \\
\cline { 2 - 5 } & $\begin{array}{l}\text { Chinese Soft-shelled } \\
\text { Turtle }\end{array}$ & Pelodiscus sinensis & Betina & $18 \mathrm{~cm}$ \\
\cline { 2 - 4 } & $\begin{array}{l}\text { Chinese Soft-shelled } \\
\text { Turtle }\end{array}$ & Pelodiscus sinensis & Betina & $21 \mathrm{~cm}$ \\
\hline Seturan & Corn snake & Pantherophis guttatus & - & - \\
\hline
\end{tabular}

Hasil wawancara dari salah satu pemelihara reptil, kura-kura ini merupakan kura-kura yang memiliki karakter agresif. Makanan kura-kura ini adalah ikan-ikan kecil, cacing, serangga, pelet dan sayuran, tetapi lebih dominan sifat karnivoranya. Kura-kura ini ditemukan di alam sebanyak dua ekor, spesies pertama berukuran 23cm, berjenis kelamin betina dan ditemukan di habitat anak sungai di daerah Tempel dengan kondisi kaki kura-kura hilang satu. Spesies kedua berukuran $15 \mathrm{~cm}$, jenis kelamin jantan dan ditemukan di pinggiran parit daerah Minomartani, Sleman. Jumlah tersebut tidak dapat menimbulkan dampak negatif bagi reptil lokal, tetapi jika kura-kura ini terlepas di alam dalam jumlah yang banyak kemungkinan akan berpotensi sebagai predator bagi spesies lokal seperti ikan-ikan kecil dan sebagai kompetitor bagi bulus jawa (Amyda cartilaginea) dalam mencari makan. 
Pelodiscus sinensis sudah dikembangbiakkan secara luas di Cina, Taiwan, Thailand dan Vietnam. Labi-labi tersebut biasanya dikirim secara besar-besaran ke Semenanjung Malaysia, Sarawak dan Sumatera. Hal ini dapat berpotensi menyebabkan masalah invasif species karena beberapa kemungkinan labi-labi tidak sengaja terlepas dan dapat membentuk populasi liar di alam (Emerson, 2004). Status konservasi untuk Pelodiscus sinensis dalam IUCN red list tergolong pada status rentan atau vulnerable (VU) dan spesies ini sekarang tidak tercantum dalam appendix CITES.

Hasil pengamatan terdapat tiga ekor labi-labi (Pelodiscus sinensis) yang ditemukan oleh pemburu atau pengepul bulus yang berasal dari habitat anak sungai Progo daerah Godean. Labi-labi pertama berjenis kelamin jantan dengan ukuran panjang tubuh $17 \mathrm{~cm}$. Labi-labi yang lain berjenis kelamin betina dengan ukuran panjang tubuh $18 \mathrm{~cm}$ dan $21 \mathrm{~cm}$. Pemburu bulus biasanya menjual hasil pemburuannya ke pengepul untuk dijadikan minyak bulus atau masakan cina. Jenis bulus yang ukurannya bisa besar (Amyda cartilaginea) harganya lebih mahal daripada jenis bulus yang ukurannya hanya kecil (Pelodiscus sinensis). Pelodiscus sinensis yang terlepas di alam dalam jumlah tersebut kemungkinan akan berpotensi sebagai kompetitor bagi Amyda cartilaginea dalam mencari makan. Perilaku dalam memburu mangsanya, Pelodiscus sinensis lebih agresif dari pada Amyda cartilaginea.

Ular Corn snake (Pantherophis guttatus) tidak berhasil ditemukan di alam, menurut hasil wawancara pemiliknya, ular ini tidak sengaja terlepas karena kelalaian. Makanan ular ini adalah burung dan mamalia kecil. Corn snake yang 
hanya satu ekor tersebut jika terlepas tidak dapat menimbulkan dampak negatif bagi reptil lokal, tetapi jika jumlahnya terlalu banyak akan menjadi kompetitor bagi ular-ular lokal seperti ular koros (Ptyas korros), ular jali (Ptyas mucosa), ular kopi (Coelognathus flavolineatus), ular lanang sapi (Coelognathus radiatus), dan lain-lain, karena jenis mangsa yang sama.

\section{KESIMPULAN}

Jenis reptil impor yang diperdagangkan maupun dipelihara di Yogyakarta ada 80 jenis yang terdiri dari satu jenis buaya kerdil (Paleosuchus palpebrosus), 14 jenis kadal (Sauria), 21 jenis ular (Serpentes), dan 44 jenis Kura-kura (Testudines). Jenis reptil impor yang ditemukan terlepas di alam yaitu dua ekor Red Eared Slider (Trachemys scripta elegans), tiga ekor Chinese Soft-shelled Turtle (Pelodiscus sinensis) dan seekor Corn snake (Pantherophis guttatus).

Red Eared Slider yang terlepas di alam dalam jumlah tersebut tidak dapat menimbulkan dampak negatif bagi reptil lokal, tetapi jika dalam jumlah yang banyak kemungkinan akan berpotensi sebagai kompetitor bagi bulus jawa (Amyda cartilaginea) dalam mencari makan. Chinese Soft-shelled Turtle yang terlepas di alam dalam jumlah tersebut kemungkinan akan berpotensi sebagai kompetitor bagi Amyda cartilaginea dalam mencari makan. Corn snake yang hanya satu ekor jika terlepas tidak dapat menimbulkan dampak negatif bagi reptil lokal, tetapi jika jumlahnya terlalu banyak akan menjadi kompetitor bagi ular-ular lokal seperti ular koros (Ptyas korros), ular jali (Ptyas mucosa), ular kopi (Coelognathus flavolineatus), ular lanang sapi (Coelognathus radiatus), dan lain-lain, karena jenis mangsa yang sama. 


\section{DAFTAR PUSTAKA}

CITES. 2014. Chekslist of CITES species database. www.cites.org. 7 Maret 2014.

Daniel, S. 2011. Perdagangan Reptilia Sebagai Binatang Peliharaan di DKI Jakarta. Naskah Skripsi-S1. Fakultas Kehutanan. IPB, Bogor.

Emerson, Farkas, B., Buzas, B. 2004. The Chinese Softshell Turtle Established in the Philippines. Turtles And Tortoises Newsletter. $07: 17$.

IUCN. 2013. IUCN Red List of Threatened Species. Version 2013.2. www.iucnredlist.org. 7 Maret 2014.

Klappenbach, L. 2013.2 Reptiles. http://animals.about.com/od/reptiles/p/reptiles.htm. 1 April 2013.

Lycons, J. A. dan Natusch, D. J. D. 2011. Wildlife Laundering Through Breeding Farms: Illegal Harvest, Population Declines and a Means of Regulating the Trade of Green Pythons (Morelia viridis) From Indonesia. Biological Conservation. (2011) : 10.1016.

Mardiastuti, A. dan Soehartono, T. 2002. Pelaksanaan Konvensi CITES di Indonesia. Japan Internasional Cooperation Agency (JICA), Jakarta.

Mardiastuti, A. dan Soehartono, T. 2003. Perdagangan Reptil Indonesia Di Pasar Internasional. Departemen Konservasi Sumberdaya Hutan, Institut Pertanian Bogor, Bogor.

Mcdiarmid, R. W., Foster, M. S., Guyer, C., Gibbons, J. W., dan Chernoff, N. 2012. Reptile Biodiversity : Standard Methods for Inventory and Monitoring. University of California Press, California.

Riyanto, A. dan Mumpuni. 2003. Metode Survei dan Pemantauan Populasi Satwa. Bidang Zoologi (Museum Zoologicum Bogoriense), Pusat Penelitian Biologi - LIPI, Bogor.

Tjakrawidjaja, A. H. 2010. Studi Fauna Eksotik Ikan Air Tawar, Reptilia dan Amphibia Asli Indonesia. LIPI. Bogor.

Uets, P. 2012. The Reptiles Data Base. http://reptile-database.org. 5 September 2012. 